\title{
Nekemijske metodeza unutar-rednu obradu tla u vinogradu ili voćnjaku
}

\section{Sažetak}

U ekološkoj proizvodnji voća i grožđa gdje se ne smiju upotrebljavati herbicidi za suzbijanje korova unutar-rednog prostora upotrebljavaju se različite nekemijske metode. Ove nekemijske metode se šire i u integriranu proizvodnju voća i grožđa. U radu su prikazani trendovi razvoja strojeva za mehaničku suzbijanje korova i termičke metode za suzbijanje korova. Kod strojeva za mehaničko suzbijanje korova ponuda proizvođača strojeva je velika, te je dosta raširena i njihova upotreba. Termičke metode suzbijanja korova još nisu toliko u upotrebi, a i ponuda strojeva za termičko suzbijanje još je relativno mala.

Ključne riječi: vinograd, voćnjak, mehanička obrada unutar rednog pojasa, termičke metode suzbijanja korova

\section{Uvod}

Posljednjih godina u Sloveniji i u drugim zemljama u Europi dosta se raspravlja o uporabi herbicida. Mišljenja o učincima glifosata su različita. Međutim, istina je da je kemijska zaštita herbicidima relativno jednostavna, učinkovita i isplativa. Nekemijske metode se također mogu koristiti za suzbijanje korova. Ove metode suzbijanja korova spadaju u metode zaštite bilja niskog rizika. Nekemijske metode moraju obavezno koristiti ekološki proizvođači, a sve se više koriste i u integriranoj proizvodnji. Cilj ovog rada je predstaviti trendove kod strojeva za nekemijsko održavanje unutar-rednog prostora u višegodišnjim nasadima.

\section{Potpora nekemijskim metodama održavanja unutar-rednog prostora u višegodišnjim nasadima}

Nekemijske metode suzbijanja korova unutar-rednog prostora u višegodišnjim nasadima Slovenija podržava programima KOPOP (Kmetijsko - okoljsko - podnebna plačila - Poljoprivredno - okolišne - klimatske isplate). U okviru KOPOP mjera definirane su: operacija za vinogradarstvo (operacija VIN) i operacija za voćarstvo (operacija SAD). U obje opcije mogu se odabrati "neobavezni zahtjevi" među koje spada VIN_MEHZ: Mehaničko suzbijanje korova (ispod čokota) i SAD_MEHZ: Mehaničko suzbijanje korova (ispod voćka). Mehaničko suzbijanje korova u unutar-redñom pojasu uključuje malčiranje, čistu obradu tla, košenje, spaljivanje, upotrebu malča, nisko rastinje - nisko rastuće nekonkurentne biljke (Vršič, 2017).

Republika Hrvatska u Programu ruralnog razvoja 2014. - 2020. (PRR) ima IAKS mjeru 10 Poljoprivreda, okoliš i klimatske promjene (M10). Potpora se može ostvariti kroz podmjeru M10.1. Plaćanja obveza povezanih s poljoprivrednom, okolišem i klimatskim promjenama koja sadrži 16 tipova operacija među kojima je i Operacija 10.1.16. Mehaničko uništavanje korova unutar redova višegodišnjih nasada (MUK). Ova operacija može se provoditi na površinama koje su u ARKOD sustavu registrirane kao višegodišnji nasadi (Kako ustvariti, 2018). 


\section{Nekemijske metode suzbijanja korova unutar reda u višegodišnjim nasadima}

Poznate su različite nekemijske metode suzbijanja korova unutar reda u višegodišnjim nasadima. Ove metode dijele se u nekoliko grupa kao što su mehaničke metode, termičke metode, električne metode, malč (organski pokrivač) itd. Ove metode spadaju u zaštitu bilja niskog rizika.

\section{Mehanička obrada unutar rednog prostora u višegodišnjim nasadima}

Strojevi za mehaničku obradu unutar rednog prostora mogu biti samostalni strojevi a mogu se priključiti i na druge strojeva kao što je malčer ili kultivator. Ako stroj za obradu unutar rednog pojasa ima aktivne radne organe onda su u većini slučajeva pogonjeni hidraulikom. Zato traktor mora imati dovoljno velik hidraulički sustav (i njegovo hlađenje). To nije toliko važno ako se sa strojem radi kratko vrijeme (npr. 20 minuta). Ali ako se tim strojem radi nekoliko sati (ili cijeli dan), tada hidraulički sustav traktora mora biti i primjerenih kapaciteta. Ako traktor nema dovoljno snažan hidraulični sustav, preporučuje se da strojevi za unutar-rednu obradu imaju vlastiti hidraulički sustav s hlađenjem ulja. Hidraulička crpka u tom primjeru pokreće se preko pogonskog vratila traktora.

Radni elementi (sklopovi) strojeva mogu se montirati samo s jedne ili s obje strane (obostrani modeli). Postoje i varijante gdje se obradi jedan red vinove loze s obje strane. Ovi strojevi mogu se montirati na prednju stranu traktora, između osovina ili straga. Kod montaže stroja između osovina traktora, stroj se nalazi na specijalnoj konzoli, koja je prilagođena za svaki traktor. Kod primjene, na bočnu stranu traktora namještenog stroja, vozač traktora ima izravnu kontrolu nad radnim elementima. Podešavanje regulacije traktora i stroja jednostavno je te omogućava kvalitetniji rad i bolje upravljanje. Kod takve montaže postoji i mogućnost da se straga priključi neki drugi stroj za međurednu obradu - malčer (Freccero i sur., 2014).

\section{Problematika}

Kriteriji za odabir odgovarajućeg radnog elementa su brzina rada, kvaliteta rada, opasnost od oštećenja čokota vinove loze ili stabla voćke, ekološka prihvatljivost, istrošenost oruđa, održivost stroja, trošak investicije i trošak upotrebe (Walg, 2016). Izbor stroja također ovisi o proizvodnom sustavu, strukturi vinograda ili voćnjaka, vrsti tla, stanju tla, nagibu itd. Kod kupnje se također mora uzeti u obzir minimalni razmak između redova (međuredni razmak) i minimalni razmak unutar reda (razmak između čokota loze u redu).

Među nedostatke ovih strojeva za unutar rednu obradu ubraja se netaknuto - neobrađeno tlo pored drveća, vinove loze ili stupova. S tim strojevima potrebno je godišnje više prolaza nego kod suzbijanja korova s herbicidima. Stoga, mehaničko suzbijanje korova može biti troškovno, energetski i radno zahtjevno (Walg, 2016). Povećana potrošnja energije može povećati i ugljični otisak u voćarstvu i vinogradarstvu. Radni elementi mogu ponekad (posebno u slučaju nepravilnog rada) oštetiti stabla voćke ili čokote vinove loze, što je još izraženije u mladim voćnjacima ili vinogradima. Takve štete mogu biti invazivno mjesto za razne bolesti (npr. rak vinove loze). Da bi strojevi pravilno radili, potrebna je relativno mala brzina vožnje koja u prosjeku iznosi između 2 - $5 \mathrm{~km} / \mathrm{h}$. Ova brzina opet zavisi o puno faktora.

Prednosti mehaničke obrade unutar-rednog prostora su rahljenje i prozračivanje tla, obrada organskog materijala, regulacija vode (za vrijeme suše), kombiniranje rada s drugim strojevima. U konačnici proizvodnja voća i grožđa jest bez upotrebe herbicida.

Većina proizvođača strojeva za unutar-rednu obradu u višegodišnjim nasadima ima u proizvodnom programu različite radne elemente, kao što su: bočna pomična kosilica, rotacijska drljača, freza za unutar rednu obradu, nož za plijevljenje - podrezivanje trave, dvo-, tro- ili četverostruki diskovi, zvjezdasti kultivatori, plužno tijelo (Bin, 2020). Zatim postoje različite čet- 
ke - čistači donjeg dijela čokota ili voćke, koje mogu imati različite duljine PVC (poliamidnih) niti (flaks), gumene trake, kožne trake itd (Uhl, 1995). Ove četke u osnovi služe za otklanjanje mladica na donjem dijelu čokota ali se njima suzbijaju i korovi (trava) unutar-rednog prostora (Hanni 2010, Porten i sur., 2015). Nazivlje ovih radnih elemenata na slovenskom jeziku još nije u potpunosti usklađeno, pa možemo imati različite nazive za istu vrstu stroja. A slično je i u drugim zemljama.

Strojevi za unutar-rednu obradu mogu se podijeliti prema vertikalnoj ili vodoravnoj osi rotacije radnih elemenata. Rotirajuće radne elemente uglavnom pokreće hidraulički motor. Prednost hidrauličkog pogona jest kontinuirana kontrola rotacije radnih elemenata stroja. Promjena brzine rotora također određuje intenzitet suzbijanja korova (veće brzine uzrokuju veći učinak i obrnuto).

Radni elementi (sklopovi) često su opremljeni hidrauličnim tasterom koji aktivira (hidraulički) pomak radnih elemenata kod dodira tastera sa stablom ili stupcem. Pomicanje radnih elemenata natrag u radni položaj najčešće se vrši pomoću opruge. To uzrokuje relativno malo neobrađenog prostora duž samog stabla ili stupca. Imamo i konstrukcije strojeva za unutarrednu obradu, koji ne trebaju pomicanja kod nailaženja na čokot ili stupac.

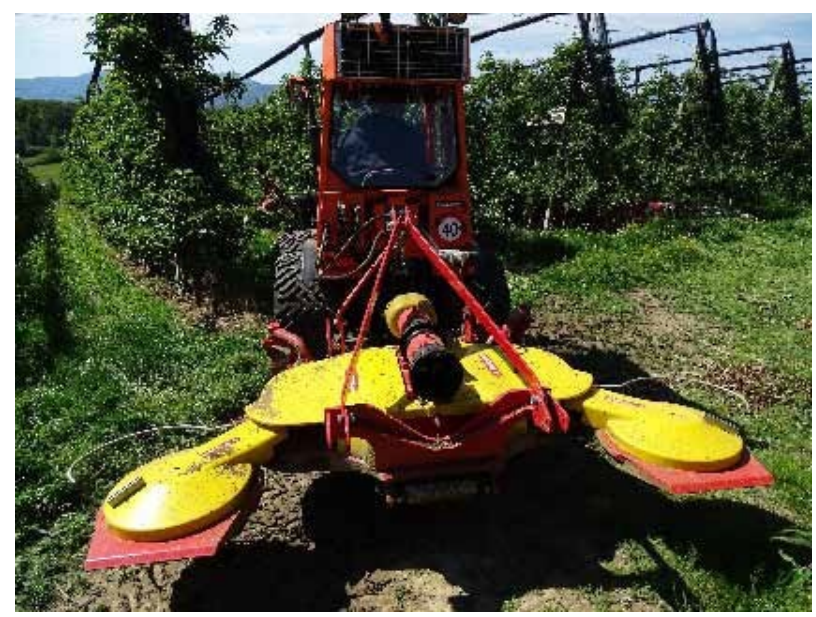

Slika 1. MalčerZUPAN2R omogućava malčiranje između redova i unutar reda na obadvije strane Figure 1. ZUPAN 2R mulcher allows mulching between rows and within rows on both sides

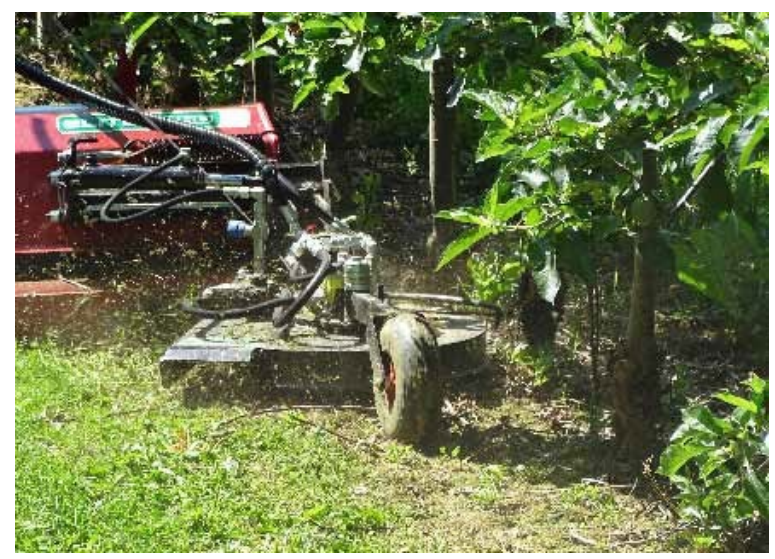

Slika 2. Bočna rotacijska kosilica INO BDR ima podesivu visinu rezanja

Figure 2. The INO BDR side rotary mower has an adjustable cutting height 

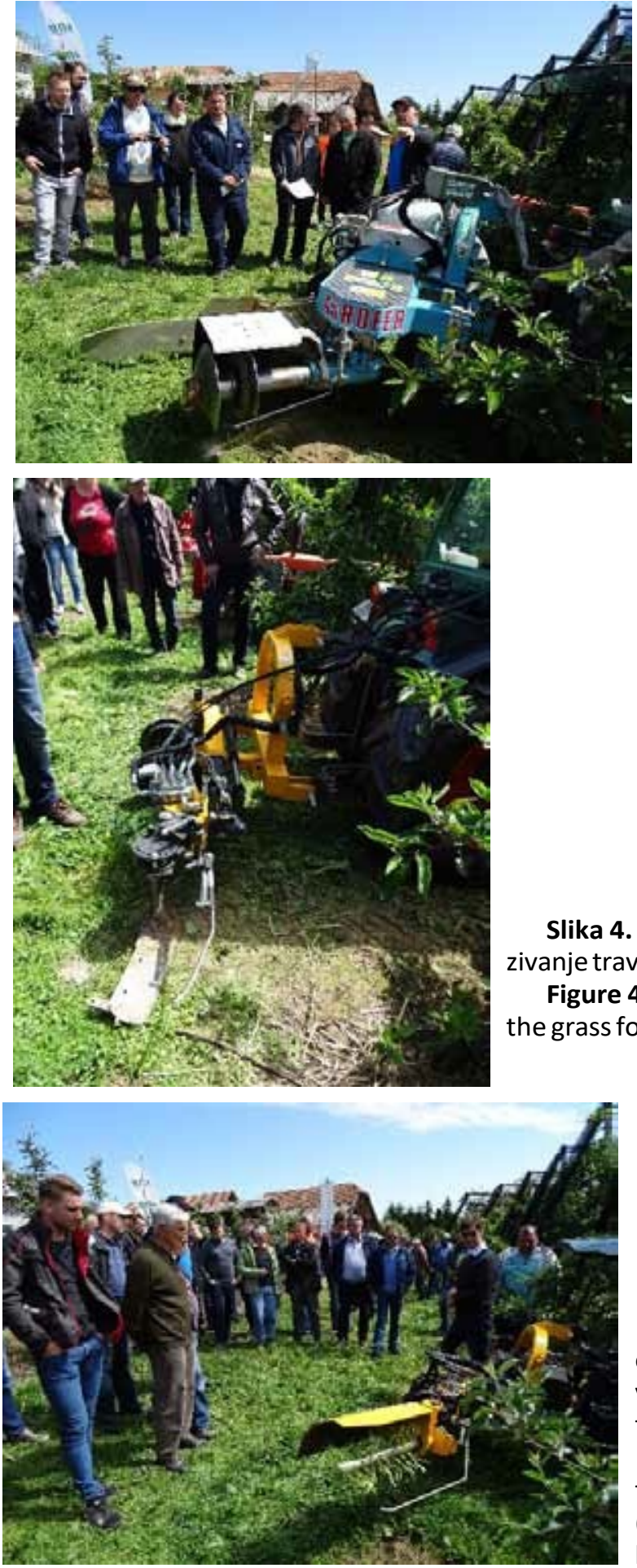

Slika 3. Talijanski proizvođač AGROFER ima dvostruke diskove sa daskom za nagrtanje zemlje (pogon diskova je preko remenskog pogona)

Figure 3. The Italian manufacturer AGROFER has double discs with a board for plowing the ground (the disc drive is via a belt drive)
Slika 4. Orizzonti nož za plijevljenje - podrezivanje trave za unutar-rednu obradu

Figure 4. Orizzonti weeding knife - trimming the grass for in-row processing
Slika 5. Orizzonti Ecology četka za održavanje prostora unutar reda (na vodoravnoj osi ima $20 \mathrm{~cm}$ duge niti flaks)

Figure 5. Orizzonti Ecology brush for maintaining space within the row (there are $20 \mathrm{~cm}$ long threads on the horizontal axis - flax) 


\section{Termičko suzbijanje korova}

Na području termičkog suzbijanja korova u višegodišnjim nasadima u Sloveniji nema puno iskustva. Ali u inozemstvu se puno toga događa. Postoje različiti postupci za termičko suzbijanje. Mogu se koristiti uređaji s otvorenim plamenom, uređaji s infracrvenim zračenjem, uređaji za pregrijavanje pare, vruća voda ili uređaji s vrućom pjenom. Također se ispituju i uređaji na principu mikrovalova i lasera. Posljednje dvije vrste uređaja još su u fazi istraživanja. Ostalo je više-manje dostupno na tržištu, mada još nisu značajno u upotrebi. Prije svega se ovi uređaji vide na sajmovima i demonstracijama tehnologije.

Termičko suzbijanje korova korištenjem otvorenog plamena metoda je koja se može upotrijebiti s vrlo jednostavnim uređajima ali ima i dosta kompleksnih strojeva. Ovi uređaji nisu novost, jer se u Sjedinjenim američkim državama koriste od 1852. godine, kada je upotrijebljen petrolej kao gorivo. Danas moderni uređaji kao gorivo koriste uglavnom plin (butan, propan, metan), a pojavili su se i gorionici na drvene pelete. Učinak spaljivanja ovisi o temperaturi plamena i vremenu djelovanja na korov. Konačni učinak spaljivanja često se primjećuje tek sljedećih dana (nakon 72 sata). Spaljivanje također treba ponoviti nekoliko puta tijekom vegetacijske sezone ( 3 do 5 puta). Prednost ove metode jest da na tlu nema štetnih ostataka. Talijansko poduzeće Tecnoecologia proizvodi uređaj Pirodiserbo za termičko suzbijanje korova otvorenim plamenom unutar-rednog pojasa u višegodišnjim nasadima. Širina termičke obrade korova iznosi do $60 \mathrm{~cm}$. Sam plamen podesiv je elektronskim upravljanjem, a komande su postavljene u kabini traktora. Uređaj omogućuje suzbijanje korova i sterilizaciju izrezanih grana, smanjujući rizik i od gljivičnih bolesti (Castaldi, 2018a, 2018b).
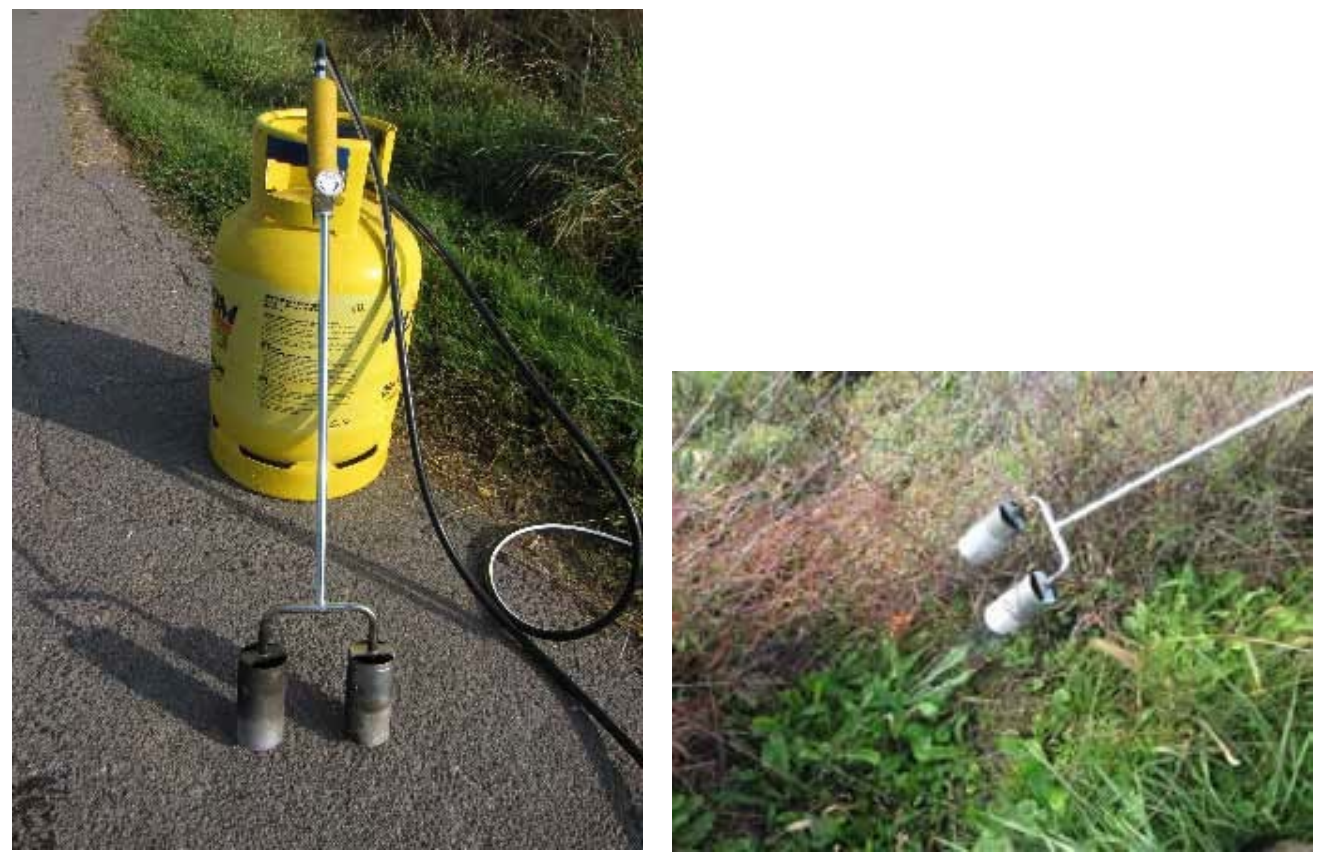

Slika 6. Jednostavni uređaj za spaljivanje korova s otvorenim plamenom

Figure 6. Simple weed burning device with open flame 

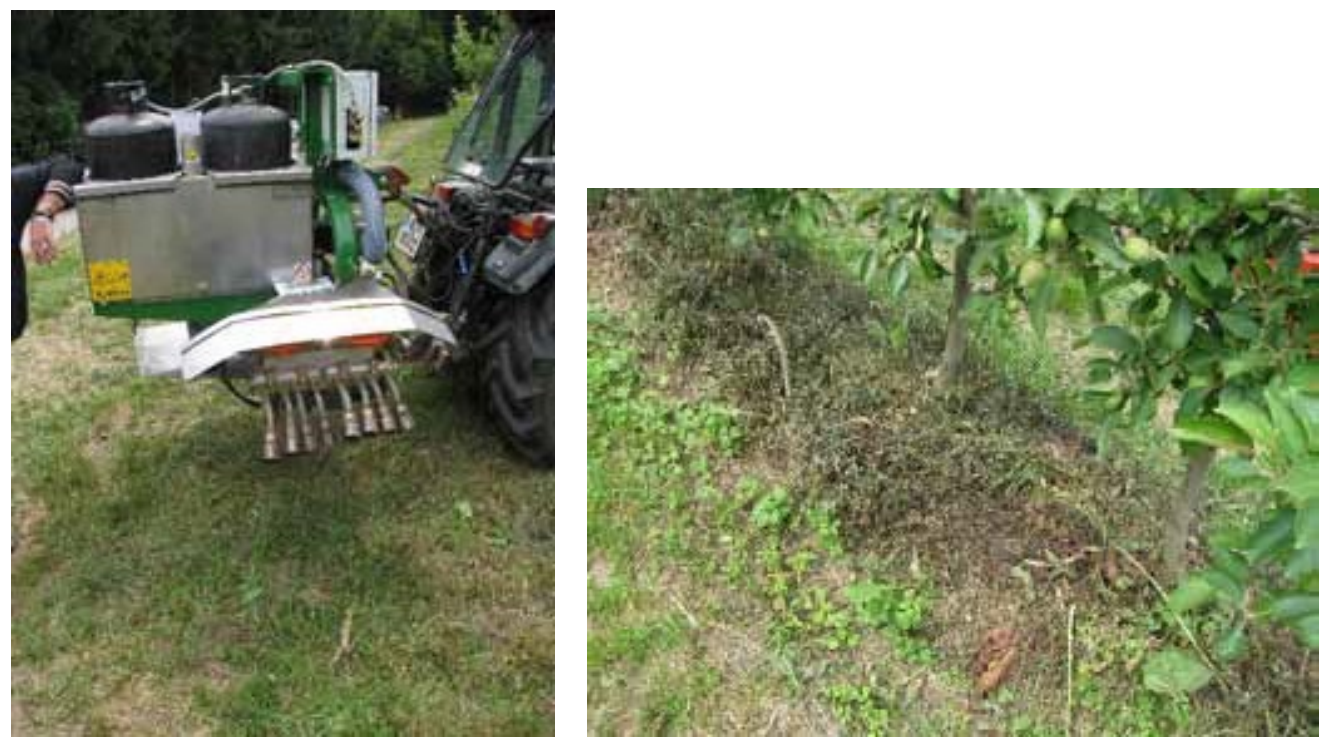

Slika 7. Tecnoecologia Pirodiserbo uređaj za termičko suzbijanje korova unutar reda sa otvorenimplamenom

Figure 7. Tecnoecologia Pirodiserbo device for thermal weed control within an open $\mathrm{fl}$

row

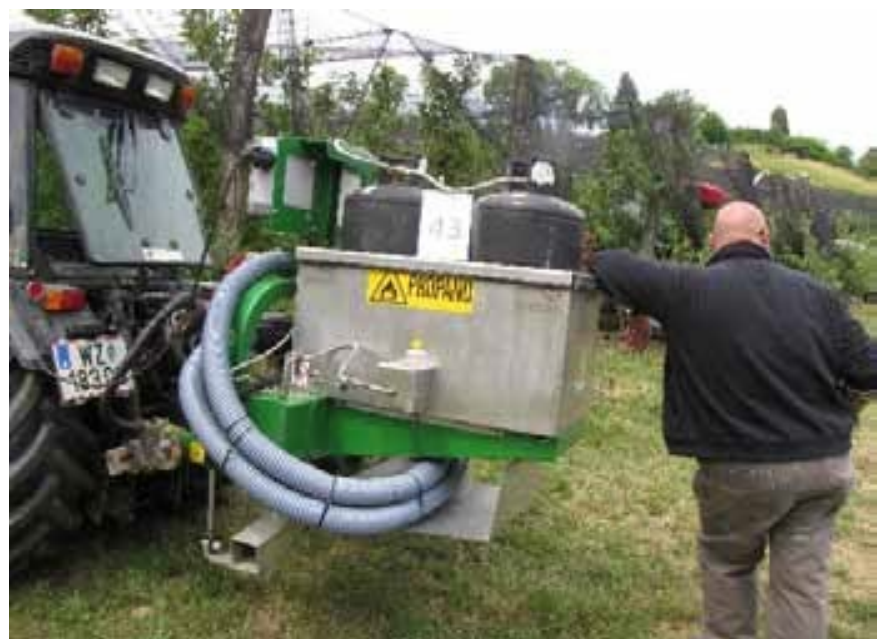

Slika 8. Većina plamenika za suzbijanje korova danas koristi plin kao gorivo (na ovom uređaju postoje spremnici s propanom)

Figure 8. Most burners for weed control today use gas as fuel (there are propane tanks on this device)

Talijanska tvrtka CS THERMOS za termičko suzbijanje korova unutar reda izradila je stroj BIODISERBO; specijalni plamenik na drvenu biomasu. Ovaj uređaj rabi se za suzbijanje korova u jednom redu ili u oba reda. Biodiserbo je zapravo njihov prilagođeni plamenik na drva. Kao gorivo upotrebljava se drveni pelet, kojega se može proizvesti i u vinogradu ako se peletiraju 
ostaci zimske rezidbe. Tada možemo govoriti i o takozvanoj kružnoj ekonomiji. Za izradu drvenih peleta iz grana nakon zimske rezidbe vinograda talijanska tvrtka Construzioni Nazzareno napravila je mobilnu peletirku smještenu na platformi traktorske prikolice.

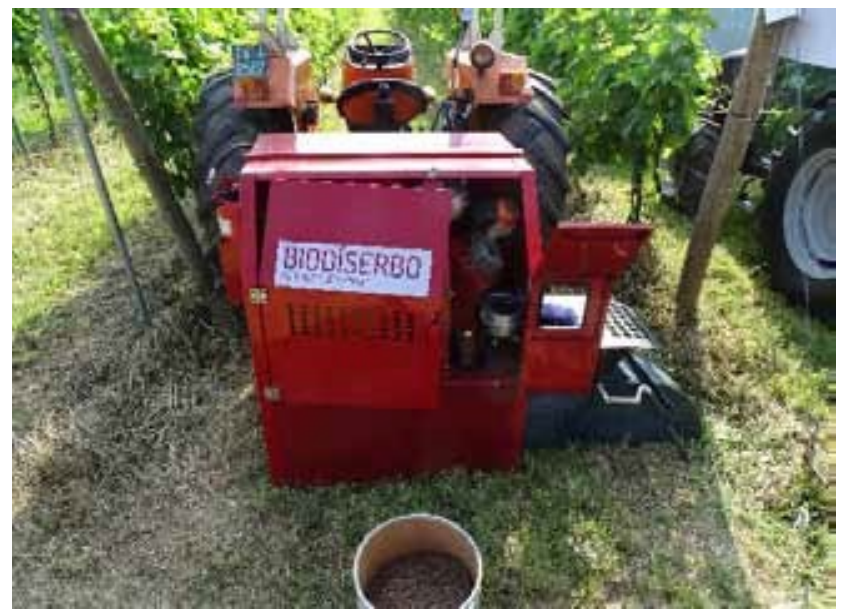

Slika 9. CS THERMOS BIODISERBO ima plamenik na drvene pelete Figure 9. CS THERMOS BIODISERBO has a wood pellet burner

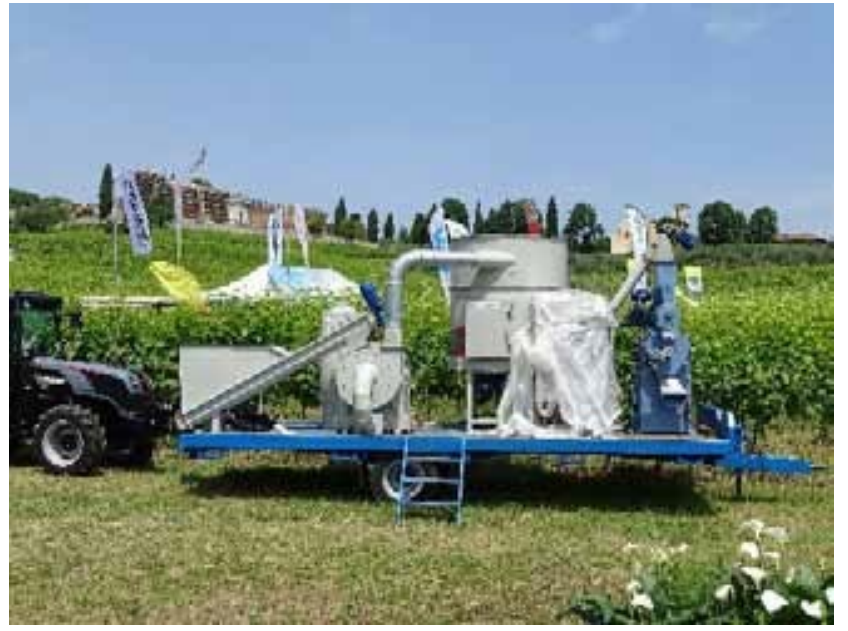

Slika 10. Mobilna peletirka Construzioni Nazzarenosmještena na platformu traktorske prikolice Figure 10. Mobile pelletizer Construzioni Nazzareno located on the platform of a tractor trailer

Talijanska tvrtka M.M. S.r.L iz Modene nudi ECO GP uređaj koji unutar reda suzbija korove uz pomoć pare. Isti može imati i 140 으, a obično je između 110 i 135 으 (ovisno o vanjskoj temperaturi). Proizvode četiri modela; sustav je patentiran. Prema njihovim podacima, godišnje bi bilo dovoljno tri prohoda stroja s parom. Brzina traktora je između 2,5 i 3,5 km/h. Pojas "tretirane zemlje" širine je $40 \mathrm{~cm}$. Plamenik djeluje na $12 \mathrm{~V}$ istosmjerno napajanje (iz baterije traktora). Uređaj čisti unutar-redni prostor od korova i istovremeno ga dezinficira. Ovaj je uređaj u 2012. godini dobio nagradu na sajmu EIMA za tehničku inovaciju. 


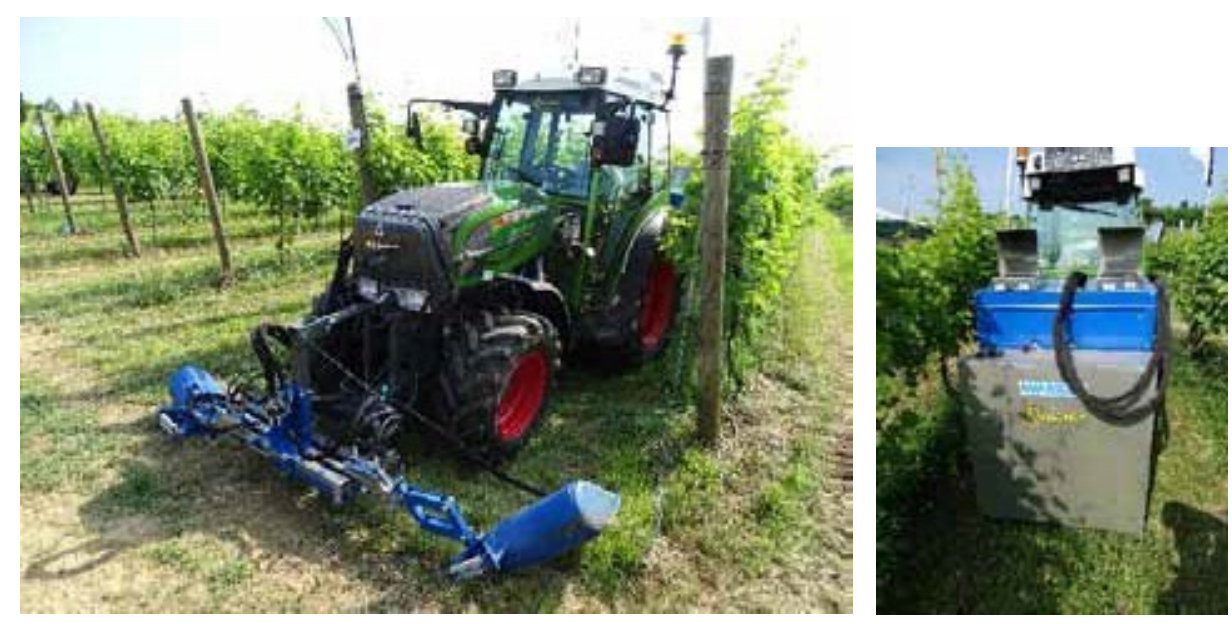

Slika 11. Talijanska tvrtka M.M. S.r.L iz Modene nudi ECO GP uređaj koji suzbija korove uz pomoć pare

Figure 11. The Italian company M.M. S.r.L from Modena offers an ECO GP device that suppresses weeds with the help of steam

Tecnovict proizvodi uređaj Schiumone - uređaj za termičko uništavanje korova s vrućom pjenom. Uređaj proizvodi vruću pjenu i aplicira je u pojas ispod drveća ili vinove loze. Pjena ima temperaturu 60ㅇ $\mathrm{i}$ kod te temperature dolazi do razgradnje (koagulacije) proteina u korovu, a zatim se biljke suše nekoliko dana (Castaldi, 2018a). Ovo tehničko rješenje je na sajmu EIMA u 2016. godini dobilo dvije nagrade, za tehničku inovaciju i za ekološko prihvatljiv uređaj.
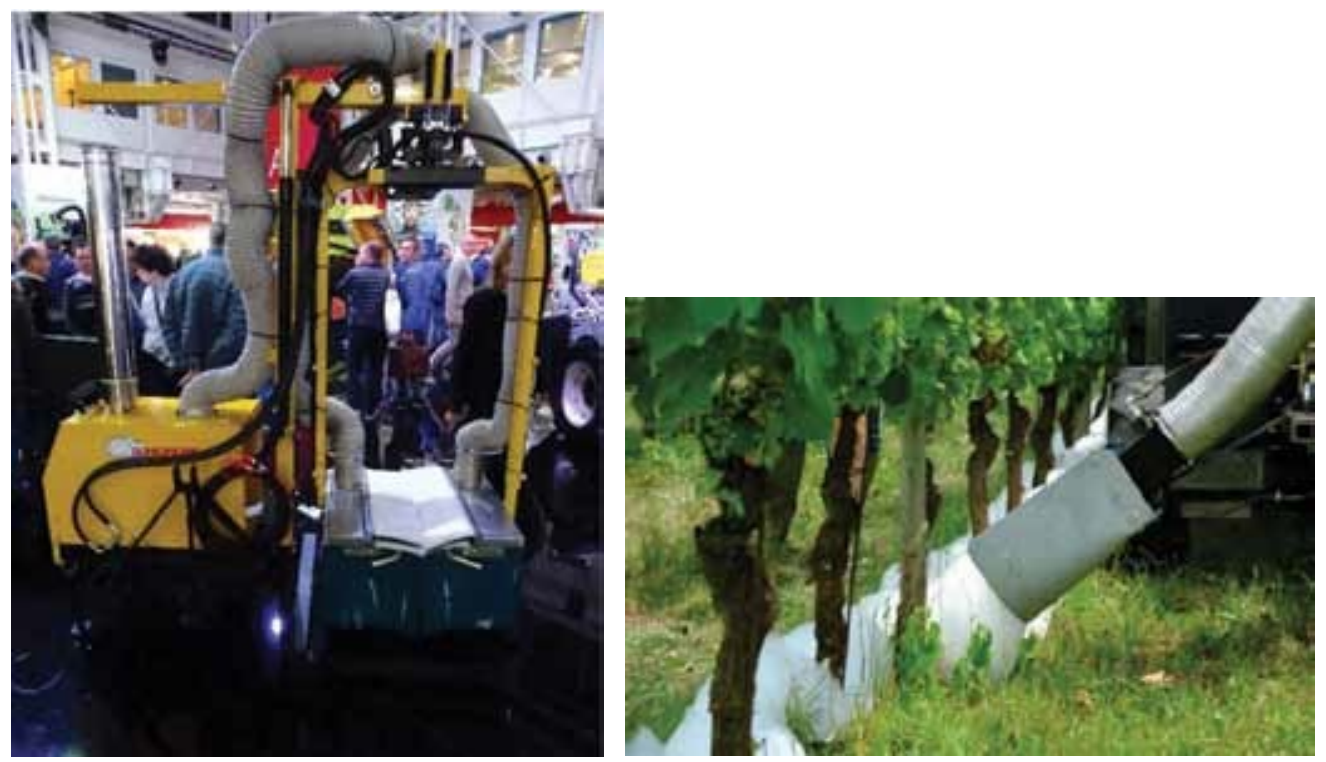

Slika 12. Tecnovict Schiumone za termičko uništavanje korova s vrućom pjenom

Figure 12. Tecnovict Schiumone for thermal weed control with hot foam 


\section{Metoda suzbijanja korova vodom pod visokim tlakom}

Korov se unutar reda može uništiti vodom pod visokim tlakom koji je proizvedenim snažnom crpkom. Voda nije vruća i ne zagrijava se. Ima temperaturu okoliša. Ova metoda stoga ne ulazi u termičke metode suzbijanja korova. I ovaj stroj može biti u izvedbi za jedno ili obostrano djelovanje (Mono ili Twin izvedba). Rezervoar sadrži vodu koju snažna klipna crpka sa 1.000 bara tlaka dovodi do kružnih radnih elemenata s četiri okomite mlaznice. Kružna ploča s mlaznicama vrti se sa 600 okretaja u minuti. Voda pod visokim tlakom uništava korov, ne samo u površini, već i u dubini tla. Utječe i na korijenski sustav. Efikasnost stroja veća je u sušnim uvjetima. Brzina kretanja traktora je oko $2,5 \mathrm{~km} / \mathrm{h}$ a potrošnja vode između 1.000 do 1.500 litara po hektaru vinograda kod međurednog razmaka 2,5 metra.
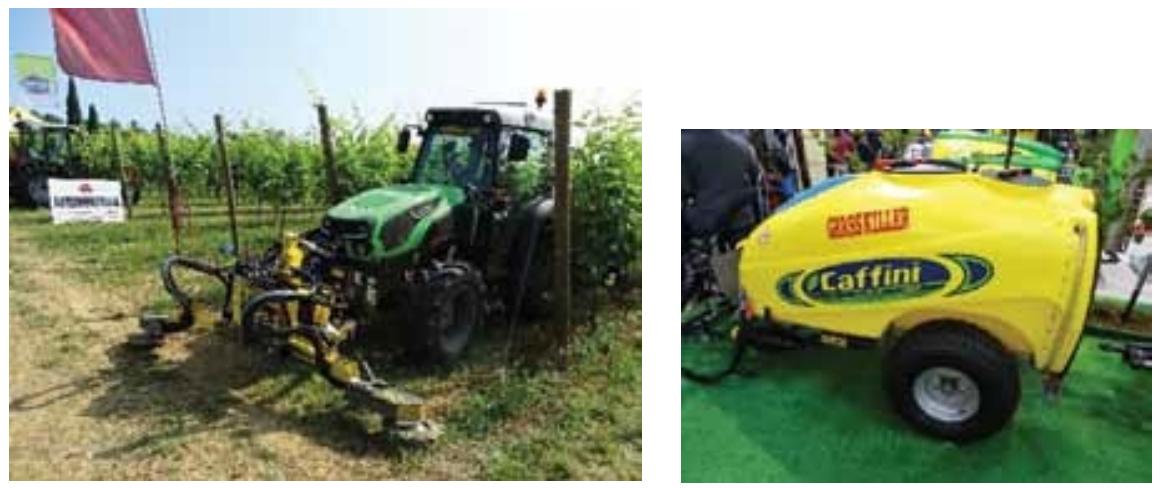

Slika 13. Caffini Grasskiller za suzbijanje korova upotrebljava vodu pod visokim tlakom

Figure 13. Caffini Grasskiller uses high pressure water to control weeds

\section{Zaključak}

Ekološki proizvođači imaju najviše iskustva sa strojevima za mehaničko suzbijanje korova unutar reda u višegodišnjim nasadima. Ovi se strojevi sve više upotrebljavaju i u integriranoj proizvodnji voća i grožđa. Odabir pravoga stroja odnosno pravih radnih elemenata nije jednostavan. Najbolje bi bilo da vinogradar ili voćar ima mogućnost višestrane odabire. Korove unutar reda možemo suzbijati i sa termičkim metodama, ali je ponuda ovakvih strojeva još mala; a još je manja njihova upotreba u višegodišnjim nasadima.

\section{Literatura}

Bin, O. (2020) Gestire il sottofila nel vigneto con mezzi meccanici e fisici. L'informatore Agrario 1/2020, $74-78$

Castaldi, R. (2018a) Pacciamatura, diserbo termico, diserbo meccanico opzioni possibili alla chimica. Vite \& Vino 1 (4), Edizioni L'informatore Agrario Srl, 35 - 39

Castaldi, R. (2018b) Pirodiserbo, gestione sostenibile del sottofila in vigneto. L'informatore Agrario 18/2018, 52 - 53

Freccero, A., Mosetti, D., Maurigh, D., Bigot, G. (2014) Vigneto: Le alternative per la gestione del sottofila. L'informatore Agrario 41/2014, 47 - 50

Hanni, E. (2010) Maschinelle Stockputzer im Vergleich. Obstbau Weinbau 6/2010, 228 - 231

Kako ostvariti potporu za IAKS mjere iz programa ruralnog razvoja Republike Hrvatske za razdoblje 2014.-2020.? 2018, Agencija za plaćanja u poljoprivredi, ribarstvu i ruralnom razvoju, Ministarstvo poljoprivrede, https://www. apprr.hr/wp-content/uploads/2018/04/Kako-ostvariti-potporu-za-IAKS-mjere-iz-PRRRH-2014.-2020..pdf (26.5.2020)

Porten, M., Regnery, D. (2015) Unterstockbürstensysteme im Überblick. Der Vinzer 3/2015, 20 - 25

Uhl, W. (1995) Unterstockbodenpflege. ATWBericht 61, ATWKTBL, Darmstadt, 22 str.

Vršič, S., Lešnik, M., Rebrnišek, A. Tehnološka navodila za izvajanje operacije Vinogradništvo. Ministrstvo za kmetijstvo, gozdarstvo in prehrano. https://www.program-podezelja.si/sl/knjiznica/147-tehnoloska-navodila-za-izvajanje-operacije-vinogradnistvo/file (26.5.2020)

Walg, O. (2016) Möglichkeiten und Grenzen der mechanischen Unterstockbodenpflege. 60. Kreuznacher Wintertagung https://www.dlr.rlp.de/internet/global/themen.nsf/747270cf8f15f0d1c1257abb0030380e/db4d519436a8a638c1 257f8b002aef6c/\$FILE/60_04_Weinbau_Walg.pdf (26.5.2020) 


\title{
Non-chemical methods for inter row cultivation in vineyards or orchards
}

\begin{abstract}
Various non-chemical methods are used in organic fruit and grape production where herbicides are not allowed to control weeds in the row space. These non-chemical methods are also spreading into integrated production of fruit and grape. The paper presents trends in the development of machines for mechanical weed control and thermal methods for weed control. In the case of mechanical weed control machines, the offer of machine is large. Their use is also quite widespread. Thermal methods of weed control are not yet widespread, and the supply of thermal control machines is still relatively small.

Key words: vineyard, orchard, mechanical cultivation for weed control in the row, thermal methods of weed control
\end{abstract}

Prodaja i projektiranje kompletnih postrojenja za vinifi

INFO (052) 449-173 www.vinoartis.hr

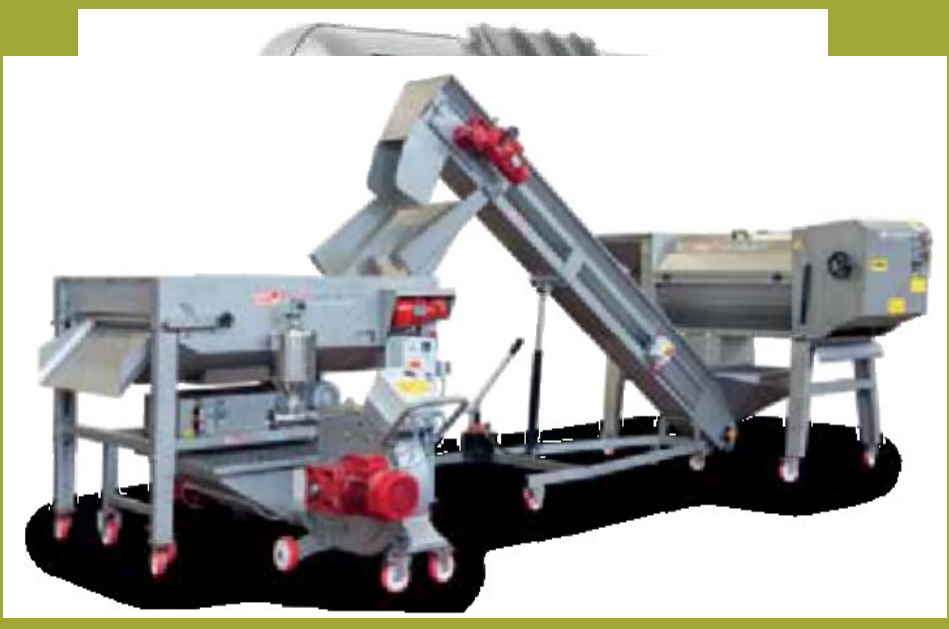

\section{0

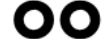 VIMOZRTIS}

VINOARTIS D.O.O.

Istarska, 29, 52463 Višnjan, Istra, Hrvatska Tel. 052/449-173 - Mob. 091/525-4632 - info@vinoartis.hr 